\title{
Aprendizagem da língua alemã em contexto universitário por meio da produção de textos associada à tradução
}

Learning German in an university context through the production of texts associated with translation

http://dx.doi.ors/10.11606/1982-88372032211

Maria Cristina Reckziegel Guedes Evangelista ${ }^{1}$

\begin{abstract}
This work is based on studies on translation as a methodological resource in teaching and learning foreign languages. The research focuses on the initial phase of learning German in the 1st year of a Language and Literature course. The students produced a self-describing text in German, which was commented and corrected through the exchange of e-mails with the teacherresearcher. Afterwards, the texts were randomly distributed to group members to be translated into Portuguese. For the analysis, the starting texts were aligned to the translations with the aid of a translation memory software. Based on CACHO E BRANCO (2014) and on criteria drawn from AUBERT (1998), SCOTT (1998 apud LIMA 2004) and CHESTERMAN (1997 apud CACHO; BRANCO 2014), the approximation of the translations with the target language (normalization), or the continuance of characteristics from the source language, as well as translation problems were analysed. These criteria proved adequate to verify how learners understand the vocabulary and structures of the German language. With similar objectives, another group of German learners compared the texts in both languages, commenting the translations. We observed that translation activities motivate learners and support learning, allowing the contact with linguistic and cultural issues.
\end{abstract}

Keywords: German learning, textproduction, translation

Resumo: Este trabalho fundamenta-se em estudos sobre a tradução como recurso metodológico no ensino e na aprendizagem de línguas estrangeiras. O contexto de pesquisa é a fase inicial de aprendizagem da língua alemã no $1^{\circ}$ ano de um curso de Letras. Os estudantes produziram um texto autodescritivo em língua alemã, comentado e corrigido pela troca de e-mails com a professora-pesquisadora. Na sequência, os textos foram distribuídos aleatoriamente aos membros do grupo, que os traduziram para o português. Para a análise, os textos-fonte foram alinhados às traduções com auxílio de um software gerenciador de memória de tradução. Com base em CACHO E BRANCO (2014) e em critérios elaborados a partir de AUBERT (1998), SCOTT (1998 apud LIMA 2004) e CHESTERMAN (1997 apud CACHO; BRANCO 2014), observou-se a aproximação das traduções com a língua-alvo (normalização)ou a manutenção de características da língua-fonte, bem como problemas tradutórios. Tais critérios mostraram-se adequados para verificar como os aprendizes compreendem vocabulário e estruturas da língua alemã. Com objetivos semelhantes, outros aprendizes de alemão compararam os textos nas duas línguas, comentando as traduções. Observou-se que atividades de tradução motivam os aprendizes e auxiliam a aprendizagem, permitindo abordar questões linguísticas e culturais.

\footnotetext{
${ }^{1}$ Universidade Estadual Paulista Júlio de Mesquita Filho, Faculdade de Ciências e Letras, Letras Modernas, Rodovia Araraquara-Jaú, Km 1, Araraquara, SP, 14800-901, Brasil. Email: macrisevangelista@gmail.com
} 


\section{A tradução no ensino e na aprendizagem de línguas estrangeiras}

A história dos métodos e das abordagens de ensino de línguas estrangeiras (LEs) mostra que a tradução foi avaliada diferentemente em cada período, podendo-se afirmar que sempre existiram dois extremos, aquele que tem a tradução como objetivo da aprendizagem de língua se aquele que proíbe seu uso em sala de aula, permitindo somente a língua-alvo.

Uma vez que as abordagens mais recentes, incluindo a abordagem comunicativa, não aceitavam a tradução em sala de aula, como discutem, p. ex., SouZA (1999) e ALVES (2007), muitos trabalhos que propõem o uso da tradução iniciam explicando essas diferentes perspectivas e discutindo prós e contras para seu emprego no ensino de línguas (cf. LuCINDO 2006; TECCHIO; BITTENCOURT 2011;BRIKS 2012;CORRÊA 2014).

Neste artigo, opta-se por não discutir esses dois opostos, adotando-se, como ponto de partida, o princípio de que a tradução pode ter papéis relevantes em contextos de ensino/aprendizagem de línguas e que é necessário compreender, fazer uso e divulgar diferentes formas de utilizá-la, para que professores e aprendizes de línguas possam conhecer as possibilidades que ela oferece como recurso metodológico e como lugar de aprendizagem da LE.

Além do interesse pelo tema e da intenção de obter maior diversificação nos procedimentos metodológicos utilizados em minha atuação como professora de alemão, motiva este trabalho a observação de que a maioria dos materiais didáticos para ensino de alemão adotados em nosso contexto universitário, geralmente importados da Europa, faz pouca ou nenhuma referência à língua materna dos aprendizes. ${ }^{2}$ Essa realidade está ligada à observação de que a maior parte dos documentos sobre políticas linguísticas na União Europeia, de 2002 a 2012, não faz "menção à tradução como uma forma de aprender, ensinar ou testar uma língua"3 (PYM; GUTIÉRREZ-COLÓN PLANA; MALMKJÆR 2013: 1), exceto pelo que é discutido no Quadro Europeu Comum de Referência para as Línguas (CONSELHO DA EUROPA2001).

\footnotetext{
${ }^{2}$ Uma exceção é o livro BlaueBlume, dos autores EICHHEIMet al., traduzido por Paulo OLIVEIRA e Susana KAMPFF LAGES (2011).

${ }^{3}$ As traduções são de minha autoria, exceto quando indicado outro tradutor.
} 
Por outro lado, a pesquisa bibliográfica desenvolvida no contexto deste trabalho revela uma vasta lista de obras sobre esse tema, como, por exemplo, a compilação de referências bibliográficas publicada por RIDD (2009), que apresenta cerca de quarenta páginas de referências, entre artigos, dissertações, teses e livros sobre essa temática.

Apesar dos inúmeros trabalhos sobre o tema, falta uma aproximação maior entre os estudos sobre a tradução e seu ensino e sobreas áreas de ensino e aprendizagem de línguas, que permita integrar essas áreas, contribuindo para o desenvolvimento de ambas (AZENHA JR. 2006; NomURA; AZENHA JR. 2009; BOHUNOVSKi 2011).

Para explicitar os papéis atribuídos à tradução no binômio ensino/aprendizagem de línguas, recorre-se a BOHUNOVSKI (2011), que apresenta as "funções metodológicas da tradução na prática de ensino", assim como a ADARVE-MARTINEZ (2012-2013). Os dois trabalhos contêm alguns paralelos entre as funções da tradução, como mostra o quadro a seguir:

\section{Quadro 1}

Papel da tradução no ensino e na aprendizagem de LEs segundo BOHUNOVSKI (2011: 210-213) e ADARVE-MARTINEZ (2012-2013)

\begin{tabular}{|c|c|}
\hline$\ldots$ & $\begin{array}{l}\text { Tradução interiorizada: "uma prática realizada por } \\
\text { todos os alunos de línguas estrangeiras", } \\
\text { "empregada de maneira consciente ou } \\
\text { inconsciente" [...] (ADARVE MARTINEZ2012-2013: } \\
6-7) \text {. }\end{array}$ \\
\hline $\begin{array}{l}\text { Tradução como "prática para explicitar, de } \\
\text { maneira efetiva, termos, expressões e estruturas } \\
\text { desconhecidas da língua estrangeira" } \\
\text { (BOHUNOVSKI 2011:210-213). }\end{array}$ & $\begin{array}{l}\text { Tradução explicativa }{ }^{4} \text { "empregada pelo } \\
\text { professor" porque "permite a rápida compreensão, } \\
\text { por parte do aluno, de falsos amigos, recursos } \\
\text { perifrásticos, provérbios ou instruções sobre como } \\
\text { executar determinada atividade" (ADARVE } \\
\text { MARTINEZ2012-2013: 7). }\end{array}$ \\
\hline $\begin{array}{l}\text { Tradução que "tem como objetivo didático } \\
\text { principal a conscientização de estruturas } \\
\text { gramaticais da língua estrangeira em contraste } \\
\text { com as da língua materna", equiparada "grosso } \\
\text { modo", à "tradução pedagógica" em WELKER } \\
\text { (2004 apud BOHUNOVSKI 2011: 209) e que tem } \\
\text { como foco principal os "aspectos formais da } \\
\text { língua estrangeira". }\end{array}$ & $\begin{array}{l}\text { Tradução pedagógica: empregada "unicamente } \\
\text { como um meio e não um fim em si mesmo", com } \\
\text { "exercícios didáticos nos quais a tradução adquira } \\
\text { um papel principal", que promovam "a melhora do } \\
\text { domínio que o aluno possui sobre a língua-meta" } \\
\text { (ADARVE MARTINEZ2012-2013: 7). }\end{array}$ \\
\hline $\begin{array}{l}\text { Tradução como "habilidade comunicativa", que } \\
\text { "deve ser praticada durante a aprendizagem"; a } \\
\text { "mediação linguística" (BOHUNOVSKI 2011: 210- } \\
\text { 213). }\end{array}$ & $\begin{array}{l}\text { Tradução como mediação: tal como descrita no } \\
\text { Quadro Europeu Comum de referência para as } \\
\text { línguas, como uma habilidade ou destreza } \\
\text { (ADARVE MARTINEZ2012-2013: 16-17). }\end{array}$ \\
\hline $\begin{array}{l}\text { Tradução que tem como "objetivo principal a } \\
\text { 'aprendizagem crítico-reflexiva', concentrando-se } \\
\text { em aspectos linguísticos e/ou culturais" } \\
\text { (BoHUNOVSKI2011:210-213). }\end{array}$ & \\
\hline
\end{tabular}

${ }^{4}$ A distinção entre tradução interiorizada e tradução explicativa foi apresentada por HURTADOALBIR (1988: 77 apud DE ARRIBA GARCIA 1996: 278). 
Esta pesquisa enfoca a tradução pedagógica, que tem como fim principal a conscientização sobre a língua e sobre estruturas gramaticais e, correspondendo à definição de WelKer (2004: 4 apud BOHUNOVSKI 2011: 209), "restringe-se aos exercícios feitos pelos alunos" e não inclui explicações dadas na língua materna pelo professor em sala.

Apesar do foco principal adotado neste trabalho, que incide no uso das estruturas gramaticais e em características do léxico, não são deixadas de lado as demais funções da tradução apresentadas no Quadro 1, no entendimento de que atividades de tradução pedagógica, com foco na língua, podem contribuir também para a aprendizagem críticoreflexiva da LE.

Para definir mais precisamente o que se entende por tradução pedagógica, esta é comparada com atradução profissional, de acordo com ALEGRE (2000: 20-21):

\section{Quadro 2}

Comparação entre tradução profissional e pedagógica segundo ALEGRE (2000: 20-21)

\begin{tabular}{|l|l|}
\hline \multicolumn{1}{|c|}{ Tradução profissional } & \multicolumn{1}{c|}{ Tradução pedagógica } \\
\hline Ênfase na tradução como produto & Ênfase na tradução como processo \\
\hline Trabalho (normalmente) individual & Trabalho (normalmente) realizado em grupo \\
\hline $\begin{array}{l}\text { A seleção do texto é feita com base em critérios } \\
\text { profissionais }\end{array}$ & $\begin{array}{l}\text { A seleção do texto é feita com base em critérios } \\
\text { didácticos (linguísticos/culturais) }\end{array}$ \\
\hline O texto é traduzido na íntegra & De um texto podemos selecionar partes \\
\hline O tradutor raramente recebe as reações do leitor & As traduções são discutidas em conjunto \\
\hline A tradução realiza-se da LE para a LM & $\begin{array}{l}\text { A tradução pode ocorrer em diversos sentidos: } \\
\text { LE - LM; LM - LE; LE - LM - LE }\end{array}$ \\
\hline $\begin{array}{l}\text { Tradução interpretativa } \\
\text { Actividade sistemática e isolada de outro tipo de } \\
\text { actividades }\end{array}$ & $\begin{array}{l}\text { Possibilidade de recurso a outro tipo de tradução } \\
\text { (p. ex.: trad. palavra a palavra; trad. interlinear) } \\
\text { atividades de aprendizagem da língua }\end{array}$ \\
\hline
\end{tabular}

\footnotetext{
5 A "tradução pedagógica" aplicada à didática de línguas, entendida como um meio para a aprendizagem, foi discutida pela primeira vez em LAVAULT (1985: 9 apud DE ARRIBA GARCIA 1996: 275-276).
} 
Guedes Evangelista, M. C. R. - Aprendizagem da língua alemã

Além das características enumeradas acima, aponta-se que a tradução pedagógica tem um "objetivo essencialmente didático" e tem o professor e o aluno como seu públicoalvo, sendo que seu foco não é voltado para a mensagem, "mas sim para a aquisição da língua e seu aperfeiçoamento” (DE ARRIBA GARCIA 1996: 276).

\subsection{Formas de inserira tradução em sala de aula}

Entre os trabalhos que apresentam listas de atividades envolvendo a tradução com fins de aprendizagem de línguas, encontram-se, em ordem cronológica, ATKINSON (1987), Butzkamm (1990), Alegre (2000), GonZÁlez Davies (2002), Arranz (2004), RoMANELli (2009), Rocha (2011), BRANCO (2009, 2012), KELLER (2012), LIBERATTI (2012).

A referência mais antiga entre eles, ATKINSON (1987), apresenta atividades como:

- tradução que inclua um item recém-ensinado, para reforçar semelhanças e diferenças entre a língua nativa e a língua-alvo;

- explicação de uma regra sobre item difícil, seguida de exercício de tradução;

- tradução de falsos cognatos conhecidos;

- tradução, para a língua materna, de textos que não foram bem escritos pelos aprendizes;

- tradução de exercícios respondidos pelos aprendizes para verificar se têm bom resultado em ambas as línguas.

Entre as referências mais recentes, LIBERATTI (2012) discorre sobre os benefícios do uso da tradução em sala de aula e propõe uma série de atividades, como:

- apresentação, pelos alunos, de frases complexas que não conseguem elaborar na L2 e elaboração dessas frases na LE, em grupo;

- tradução de expressões idiomáticas da L1 para a L2 e vice-versa;

- tradução de texto contendo falsos cognatos;

- legendagem e comparação com as legendas originais;

- interpretação de uma cena oral, representada por colegas.

Não há muitos trabalhos que associem atividades de tradução com textos produzidos pelos aprendizes, mas RAZUK (2004) apresenta uma proposta nesse sentido. Em sua prática de professora de português como língua estrangeira, a autora observou que, ao solicitar que os alunos produzissem um texto na língua-alvo, muitos deles escreviam esse texto na língua materna e depois o traduziam, com resultados nem sempre 
Guedes Evangelista, M. C. R. - Aprendizagem da língua alemã

satisfatórios. Seu trabalho adota a perspectiva, ainda hoje pouco explorada, de relacionar os estudos da tradução e o ensino de LE.

A autora avaliou textos escritos por aprendizes de português como língua estrangeira na língua-alvo e utilizou questionários, para verificar as seguintes hipóteses de pesquisa (RAZUK 2004: 3-4):

(a) os aprendizes adotam a tradução palavra-por-palavra, fazendo uso de dicionário bilíngue, partindo da ideia de que existe uma "relação biunívoca" entre as línguas;

(b) os aprendizes fazem uso de estratégias, por exemplo, quando o dicionário não oferece soluções, tais como:

explicar o sentido de uma palavra/expressão ou descrever a sua situação de uso; simplesmente omitir o termo; resumir o texto imaginado; usar a palavra na sua própria língua; abrasileirar/aportuguesar; ou escolher uma palavra com significado semelhante;

(c) os aprendizes constroem "uma terceira língua, situada entre a LM e a LE", que nem sempre é compreensível.

Entre as conclusões apresentadas, a autora aponta que as estratégias utilizadas pelos aprendizes são semelhantes àquelas empregadas pelos tradutores e considera que o professor de línguas deve discutir essa temática com os aprendizes, esclarecendo questões como a tradução palavra-por-palavra, o uso de estratégias e suas consequências para o texto final (RAZUK2004: 16-17).

Dez anos mais tarde, LAIÑO (2014) desenvolveu uma proposta de tradução de textos publicitários incluídos numa sequência didática, com aprendizes de espanhol de um curso de graduação em Letras. Como fundamentação teórica, entre outros trabalhos, foi adotada a perspectiva de NORD (2010 apud LAIÑO 2014), segundo a qual o texto a ser traduzido deve ser analisado previamente pelo tradutor, com os seguintes objetivos:

\section{Quadro 3}

Modelo de análise textual prévia à tradução segundo NORD (2010: 1)

(a) Procurar uma compreensão ampla e profunda do texto-base e a interpretação de sua mensagem;

(b) Explicar as estruturas linguístico-textuais, relacionando-as, [...], com o sistema e a norma da língua-base;

(c) Determinar a função de cada elemento textual no contexto da situação comunicativa;

(d) Oferecer ao tradutor uma base confiável para toda decisão que seja necessário tomar durante o processo de tradução.

(NORD 2010: 1, apud LAIÑO 2014: 71-72, tradução de Laiño). 
Na pesquisa aqui apresentada, buscando uma aproximação com o que postula o modelo de análise textual prévia à tradução, foram escolhidos textos produzidos por aprendizes de alemão, para que estes pudessem traduzir conteúdos e estruturas já conhecidos, de modo que suas decisões para a tradução não fossem afetadas por dificuldades na compreensão do texto.

\section{Temas abordados na produção textual e na tradução}

A escolha dos temas para a produção textual orientou-se inicialmente pelo material didático utilizado nas disciplinas de Língua Alemã em nossa instituição, Studio d Al (FUNK; KUHN; DEMME 2005), no qual as primeiras unidades abordam ações comunicativas como saudação, apresentação pessoal, diálogo sobre cidades e atrações turísticas, sobre formas de moradia e profissões, entre outros.

Tais temas estão associados ao que é estabelecido pelo Quadro Europeu Comum de Referência para as Línguas - QECR (CONSELHO DA EUROPA2001a) e pelo Portfólio Europeu de Línguas (CONSElHO DA EUROPA2001b) para níveis iniciais. No QECR, os níveis comuns de referência A1 e A2 da escala global descrevem as seguintes características de um "aprendiz elementar", das quais assinalo em negrito as que estão relacionadas aos temas abordados nas redações:

$\underline{\mathrm{O}}$ aprendiz no nível A1:É capaz de compreender e usar expressões familiares e quotidianas, assim como enunciados muito simples, que visam satisfazer necessidades concretas. Pode apresentar-se e apresentar outros e é capaz de fazer perguntas e dar respostas sobre aspectos pessoais como, por exemplo, o local onde vive, as pessoas que conhece e as coisas que tem. Pode comunicar de modo simples, se o interlocutor falar lenta e distintamente e se mostrar cooperante.

O aprendiz no nível A2:É capaz de compreender frases isoladas e expressões frequentes relacionadas com áreas de prioridade imediata (p. ex.: informações pessoaise familiares simples, compras, meio circundante). É capaz de comunicar em tarefas simples e em rotinas que exigem apenas uma troca de informação simples e directa sobre assuntos que lhe são familiares e habituais. Pode descrever de modo simples a sua formação, o meio circundante e, ainda, referir assuntos relacionados com necessidades imediatas (CONSELHO DA EUROPA 2001a: 49).

O Portfólio Europeu de Línguas constitui um instrumento para registro do percurso individual na aprendizagem de línguas (CONSELHO DA EUROPA2001b). Esse documento traz, em sua grade de autoavaliação, no que tange à produção escrita, parâmetros que também se relacionam aos temas escolhidos para a produção textual nesta pesquisa: 
a) nível A1: "sei escrever frases simples acerca de mim próprio, por exemplo, "Vivo em...", "Tenho X irmãos e irmãs", etc.

b) nível A2: "sei escrever frases simples acerca da minha família, escola, passatempos, férias, preferências..." (CONSELHO DA EUROPA2001b: 39).

Vale ainda pontuar que esse recorte, que parte de algumas habilidades e/ou ações comunicativas específicas e que tem foco na tradução pedagógica voltada para a aquisição e para o aperfeiçoamento no uso da LE, não exclui as questões interculturais, pois, como aponta o QECR:

$\mathrm{O}$ aprendente não adquire pura e simplesmente dois modos de actuar e de comunicar distintos e autônomos. $\mathrm{O}$ aprendente da língua torna-se plurilíngue e desenvolve a interculturalidade. As competências linguísticas e culturais respeitantes a uma língua são alteradas pelo conhecimento de outra e contribuem para uma conscientização, uma capacidade e uma competência de realização interculturais (CONSELHO DA EUROPA 2001a: 73).

\section{Considerações teóricas e práticas sobre a análise das traduções}

\subsection{Critérios de análise}

Após discutir o que significa empregar a tradução no ensino e na aprendizagem de LE se a perspectiva adotada para a produção de textos associada à tradução, apresenta-se, neste item, o aporte teórico que orienta a análise das traduções desenvolvidas pelos estudantes.

Com base nos procedimentos técnicos da tradução(VINAY; DARBELnET1958 apud AuBERT1998: 102, grifo do autor), Aubert descreve treze modalidades de tradução, adotando-as como "um modelo descritivo mediante o qual o grau de diferenciação linguística entre o texto-fonte e o texto-alvo poderá ser medido e quantificado" ou um modelo que mede o "grau de proximidade/distância entre o texto original e o texto traduzido" (AUBERT 1998: 103).

A pergunta de pesquisa para adoção desse modelo havia sido "quantos \% do texto original reaparecem no texto traduzido sob forma de determinada modalidade?" (AUBERT 1998: 103). Esse modelo toma como unidade tradutória a palavra, e não o sintagma ou a oração. Porém, como o autor explica, isso não significa que as palavras sejam analisadas fora de seu contexto (AUBERT 1998: 104). 
As treze modalidades de tradução são apresentadas no quadro que segue:

Quadro 4

Modalidades de tradução segundo AUBERT (1998: 102-111)

\begin{tabular}{|c|c|}
\hline Omissão & $\begin{array}{l}\text { "Ocorre [...] sempre que um dado segmento textual do Texto-Fonte e a informação } \\
\text { nele contida não podem ser recuperados no Texto-Meta." }\end{array}$ \\
\hline Transcrição & $\begin{array}{l}\text { "Inclui segmentos textuais que pertençam ao acervo de ambas as línguas envolvidas } \\
\text { (p. ex. algarismos, fórmulas algébricas e similares) ou, ao contrário, que não } \\
\text { pertençam nem à Língua-Fonte nem à Língua-Meta, e sim a uma terceira língua e, que, } \\
\text { na maioria dos casos, seriam considerados empréstimos no Texto-Fonte (como, por } \\
\text { exemplo, frases, aforismos latinos - alea jacta est)." [...] e também "sempre que o } \\
\text { Texto-Fonte contiver uma palavra ou expressão emprestada na Língua-Meta." }\end{array}$ \\
\hline Empréstimo & $\begin{array}{l}\text { Inclui "[...] um segmento textual do Texto-Fonte reproduzido no Texto-Meta com ou } \\
\text { sem marcadores de empréstimo (aspas, itálico, negrito, etc.)." }\end{array}$ \\
\hline Decalque & $\begin{array}{l}\text { Contém uma "palavra ou expressão emprestada da Língua-Fonte mas que (i) foi } \\
\text { submetida a certas adaptações gráficas e/ou morfológicas para conformar-se às } \\
\text { convenções da Língua-Fonte e (ii) não se encontra registrada nos principais } \\
\text { dicionários recentes da Língua-Fonte [...]". }\end{array}$ \\
\hline $\begin{array}{l}\text { Tradução } \\
\text { literal }\end{array}$ & $\begin{array}{l}\text { Corresponde à “[...] tradução palavra-por-palavra e em que, comparando-se os } \\
\text { segmentos textuais fonte e meta, se observa: (i) o mesmo número de palavras, (ii) na } \\
\text { mesma ordem sintática, (iii) empregando as 'mesmas' categorias gramaticais e (iv) } \\
\text { contendo as opções lexicais que, no contexto específico, podem ser tidas por sendo } \\
\text { sinônimos interlinguísticos [...]". }\end{array}$ \\
\hline Transposição & $\begin{array}{l}\text { Ocorre "[...] sempre que um dos três primeiros critérios que definem a tradução literal } \\
\text { deixa de ser satisfeito }[\ldots] \text { ". }\end{array}$ \\
\hline $\begin{array}{l}\text { Explicitação/ } \\
\text { Implicitação }\end{array}$ & $\begin{array}{l}\text { Ocorre quando "[...] informações implícitas contidas no Texto-Fonte se tornam } \\
\text { explícitas no Texto-Meta (por exemplo, por meio de aposto explicativo ou parentético, } \\
\text { paráfrase, nota de rodapé, etc.) ou, ao contrário, informações explícitas contidas no } \\
\text { Texto-Fonte e identificáveis com determinado segmento textual, tornam-se referências } \\
\text { implícitas". }\end{array}$ \\
\hline Modulação & $\begin{array}{l}\text { Ocorre "[...] sempre que um determinado segmento textual for traduzido de modo a } \\
\text { impor um deslocamento perceptível na estrutura semântica de superfície, embora } \\
\text { retenha o mesmo efeito geral de sentido [...]." }\end{array}$ \\
\hline Adaptação & $\begin{array}{l}\text { "[...] denota uma assimilação cultural"; [...] estabelecendo "uma equivalência parcial } \\
\text { de sentido, tida por suficiente para os fins do ato tradutório" }[\ldots]\end{array}$ \\
\hline $\begin{array}{l}\text { Tradução } \\
\text { intersemiótica }\end{array}$ & $\begin{array}{l}\text { Ocorre quando "[...] figura, ilustrações, logomarcas, selos, brasões e similares } \\
\text { constantes do Texto-Fonte vêm reproduzidos no Texto-Meta como material textual } \\
{[\ldots] \text { ". }}\end{array}$ \\
\hline Erro & $\begin{array}{l}\text { Refere-se a "[...] casos evidentes de "gato por lebre" (grifo do autor)", em que há } \\
\text { problemas na tradução. }\end{array}$ \\
\hline Correção & $\begin{array}{l}\text { Caracteriza-se por correção realizada na tradução quando "o Texto-Fonte contém erros } \\
\text { factuais e/ou linguísticos, inadequações e gafes". }\end{array}$ \\
\hline Acréscimo & $\begin{array}{l}\text { Refere-se a "segmento textual incluído no Texto-Alvo pelo tradutor por sua própria } \\
\text { conta, ou seja, não motivado por qualquer conteúdo explícito ou implícito do texto } \\
\text { original." }\end{array}$ \\
\hline
\end{tabular}


Guedes Evangelista, M. C. R. - Aprendizagem da língua alemã

As traduções também podem ser analisadas segundo a normalização, definida como "uma tendência para exagerar características da língua-meta (LM) e para adequar-se aos seus padrões típicos" (BAKER 1996: 180-184 apud CAMARGO 2010: 221). Também podese associar a normalização a "opções feitas pelo tradutor, algumas vezes consciente, outras inconscientemente, ao traduzir características textuais idiossincráticas, de tal modo que elas se adaptem à forma e à norma da língua e cultura de chegada" (SCOTT 1998: 112 apud LiMA 2004: 56).

Com base no exposto por Lima (2004) de acordo com o trabalho de SCOTT (1998), são apresentadas onze características da normalização:

Quadro 5

Normalização segundo SCOTT (1998 apud LIMA 2004)

\begin{tabular}{|c|c|}
\hline Pontuação & $\begin{array}{l}\text { Uso de vírgulas, ponto e vírgula, ponto final, reticências, travessões etc. } \\
\text { (LIMA 2004: 117-121) }\end{array}$ \\
\hline Padrões de repetição & Repetição de vocábulos ou fragmentos do texto (LIMA 2004: 122-125). \\
\hline Metáforas incomuns & $\begin{array}{l}\text { Modificações na tradução para facilitar a compreensão (LIMA 2004: 125- } \\
\text { 128). }\end{array}$ \\
\hline $\begin{array}{l}\text { Comprimento dos textos } \\
\text { e de sentenças }\end{array}$ & $\begin{array}{l}\text { Modificação do comprimento em termos de itens (tokens) (LIMA 2004: } \\
\text { 128-130). }\end{array}$ \\
\hline Omissão & $\begin{array}{l}\text { Omissão que ocorre porque o termo não foi encontrado, para evitar } \\
\text { redundâncias ou quando o termo é vago ou ambíguo e dificulta a } \\
\text { compreensão (LIMA 2004: 131). }\end{array}$ \\
\hline Acréscimo & $\begin{array}{l}\text { "A informação adicional que um tradutor pode ter que adicionar à sua } \\
\text { versão é geralmente cultural (devido à diferença entre a LF e a cultura da } \\
\text { LM), técnica (relativa ao tópico) ou linguística (explicando uso incomum } \\
\text { das palavras) e, ao contrário do original, é dependente das exigências de } \\
\text { seu público" (NEWMARK 1988: 91). }\end{array}$ \\
\hline $\begin{array}{l}\text { Estruturas sintaticamente } \\
\text { complexas }\end{array}$ & Mudanças na ordem das palavras (LIMA, 2004: 133-134). \\
\hline $\begin{array}{l}\text { Mudança de linguagem } \\
\text { coloquial para formal }\end{array}$ & $\begin{array}{l}\text { Relação com as questões de registro(HALLIDAY } 1978 \text { apud LiMA 2004: } \\
\text { 134-135). }\end{array}$ \\
\hline $\begin{array}{l}\text { Substituição de } \\
\text { colocações menos } \\
\text { comuns por mais comuns }\end{array}$ & $\begin{array}{l}\text { Substituição para, por exemplo, traduzir palavras que aparecem somente } \\
\text { uma vez no texto e são de difícil compreensão (SCOTT } 1998 \text { apud LIMA } \\
\text { 2004: 136). }\end{array}$ \\
\hline $\begin{array}{l}\text { Outras mudanças na } \\
\text { tradução }\end{array}$ & $\begin{array}{l}\text { Mudanças que não se enquadram nas categorias anteriores, por exemplo, } \\
\text { quando pronomes na função de sujeito ou de objeto são substituídos por } \\
\text { substantivos, ou são excluídos por não serem necessários na língua-alvo } \\
\text { (LIMA 2004: 137-141). }\end{array}$ \\
\hline
\end{tabular}

CHESTERMAN (1997: 89) denomina estratégias de tradução as "operações que um tradutor pode realizar durante a formulação do texto-alvo [...]", que constituem "formas de manipulação textual explícita" (grifo do autor). O autor divide essas estratégias em 
Guedes Evangelista, M. C. R. - Aprendizagem da língua alemã

três grupos e comenta que podem ocorrer sobreposições entre eles: estratégias sintáticas, semânticas e pragmáticas.

CACHO E BRANCO (2014)estudam a relação entre tradução e aprendizagem de LEs, avaliando traduções realizadas por aprendizes de inglês de um curso de graduação em Letras. Elas examinam a ocorrência das estratégias sintáticas descritas por CHESTERMAN (1997: 94-101),que são explicadas e, em parte, traduzidas pelas autoras da seguinte maneira:

\section{Quadro 6}

Estratégias de tradução segundo CHESTERMAN (1997: 94-101) apud CACHO; BRANCO (2014: 61)

\begin{tabular}{|c|c|}
\hline Tradução literal & $\begin{array}{l}\text { Ocorre quando a tradução é "mais aproximada da língua de origem, respeitando a } \\
\text { gramática". }\end{array}$ \\
\hline $\begin{array}{l}\text { Empréstimo ou } \\
\text { calque }\end{array}$ & "Inclui o empréstimo de itens e de sintagmas." \\
\hline Transposição & "Indica mudança de classe de palavras." \\
\hline Troca de unidade & $\begin{array}{l}\text { "Ocorre quando uma unidade (morfema, palavra, frase, oração, sentença } \\
\text { ouparágrafo) no texto de origem é traduzida por outra diferente no texto de } \\
\text { chegada." }\end{array}$ \\
\hline $\begin{array}{l}\text { Mudança na } \\
\text { estrutura da frase }\end{array}$ & $\begin{array}{l}\text { "Inclui modificações no nível da frase: modificações de número, de exatidão e no } \\
\text { grupo nominal, na pessoa, no tempo e no modo do grupo verbal." }\end{array}$ \\
\hline $\begin{array}{l}\text { Mudança na } \\
\text { estrutura da } \\
\text { oração }\end{array}$ & $\begin{array}{l}\text { "Inclui modificações relacionadas com a estrutura da oração em termos dos } \\
\text { constituintes da frase (por exemplo: voz passiva vs. voz ativa, troca na ordem dos } \\
\text { constituintes da oração)." }\end{array}$ \\
\hline $\begin{array}{l}\text { Mudança na } \\
\text { estrutura da } \\
\text { sentença }\end{array}$ & "Modifica a estrutura da unidade da sentença." \\
\hline Mudança coesiva & $\begin{array}{l}\text { "Afeta a referência intratextual, elipse, substituição, pronominalização e repetição } \\
\text { ou o uso de conectores de vários tipos." }\end{array}$ \\
\hline Troca de nível & $\begin{array}{l}\text { Muda "o modo de expressão de itens particulares [...] de um nível para outro. Os } \\
\text { níveis são o fonológico, o morfológico, o sintático e o lexical". }\end{array}$ \\
\hline $\begin{array}{l}\text { Mudança de } \\
\text { esquema }\end{array}$ & $\begin{array}{l}\text { "Envolve a incorporação de esquemas retóricos como o paralelismo, arepetição, a } \\
\text { aliteração, o ritmo métrico etc." }\end{array}$ \\
\hline
\end{tabular}

\subsection{Comparação entre o texto-fonte e a tradução}

A comparação entre diferentes traduções de um mesmo texto é uma das áreas de pesquisa em tradução (WiLliams; CHESTERMAN 2012: 6-7) e permite explorar ampla gama de questões, como, por exemplo, semelhanças e diferenças com o texto-fonte, aspectos estilísticos dos tradutores, estratégias utilizadas e problemas na tradução, entre outros. 
Guedes Evangelista, M. C. R. - Aprendizagem da língua alemã

De forma análoga, a comparação de uma tradução com o texto-fonte permite estudar tópicos semelhantes, analisando, por exemplo, as escolhas linguísticas e lexicais realizadas pelos tradutores. Pensando em tais possibilidades de análise, esta pesquisa direciona-se à comparação entre textos produzidos em alemão por aprendizes de alemão como LE em fases iniciais de aprendizagem e as traduções desses textos para o português, feitas também por aprendizes, buscando abordar questões associadas ao vocabulário e à estrutura das duas línguas.

Parte-se do arcabouço teórico apresentado anteriormente e das primeiras observações realizadas no corpus da pesquisa, propondo-se três categorias principais de análise, que são:

- Normalização, vista como a aproximação do texto traduzido com a língua-alvo;

- Manutenção de características da língua-fonte por meio da tradução literal;

- Problemas na tradução por falta de compreensão da língua-fonte.

Embora mantendo o foco nas questões linguísticas, é necessário que os aprendizes sejam levados a refletir sobre a tradução "não como troca de segmentos textuais isolados - palavras, sintagmas, orações - de uma língua para a outra, mas como o transporte de textos de uma língua/cultura para outra” (AZENHA JR. 2006: 162).

Assim, mesmo que as atividades de tradução pedagógica voltem-se inicialmente para a estrutura da LE, as discussões sobre o texto-alvo incluem questões mais amplas sobre a tradução:

Tanto no ensino de língua estrangeira (LE) quanto no de tradução, tem-se como objetivo contrastar, no trato com o texto de trabalho, não só os mecanismos de funcionamento das línguas-objeto, como também o seu uso contextualizado, que consiste em analisar as funções comunicativas da linguagem e as convenções socioculturais pelas quais se pautam os comportamentos linguísticos em cada comunidade cultural (NOMURA; AZENHA JR.2009).

\subsection{Programas de gerenciamento de memórias de tradução e bi-textos}

Os procedimentos adotados para análise das traduções têm como ponto de partida meu projeto de pesquisa sobre a Tradução Assistida por Computador (TAC, em inglês, Computer-AssistedTranslation), mais especificamente sobre o uso de ferramentas de gerenciamento de memória de tradução em contextos de ensino de aprendizagem de LE. 
Guedes Evangelista, M. C. R. - Aprendizagem da língua alemã

A TAC compreende a utilização de ferramentas como dicionários, glossários, programas de tradução automática, ferramentas de gerenciamento de terminologia, sistemas de gerenciamento de projeto e fluxo de trabalho, memórias de tradução e concordanciadores bilíngues (FROMM 2009: 4-11), além de sites de busca e corpora eletrônicos, entre outros.

Algumas dessas ferramentas trabalham com "bi-textos", textos paralelos obtidos pelo alinhamento do texto-fonte com o texto-alvo, que são, em princípio, textos "semiindependentes" um do outro, pois cada um destina-se a um público-alvo diferente, falantes de línguas diferentes (HARRIS 1988: 1). No entanto, como aponta o mesmo autor, um bi-texto constitui o texto-alvo para os tradutores, uma vez que eles constantemente necessitam analisar e comparar os textos nos dois idiomas. Nesse sentido, o bi-texto é um excelente recurso para aprendizes de LEs, pois as atividades de tradução poderão levá-los à reflexão sobre as duas línguas em questão.

O software de gerenciamento de memórias de tradução em foco nesta pesquisa é o SDL-Trados, cujas licenças para uso em instituições de ensino foram adquiridas em 2013, com verba do Programa de Melhoria do Ensino de Graduação desta faculdade, e instaladas no Laboratório de Idiomas da mesma instituição.

A interface desse software tem a seguinte configuração:

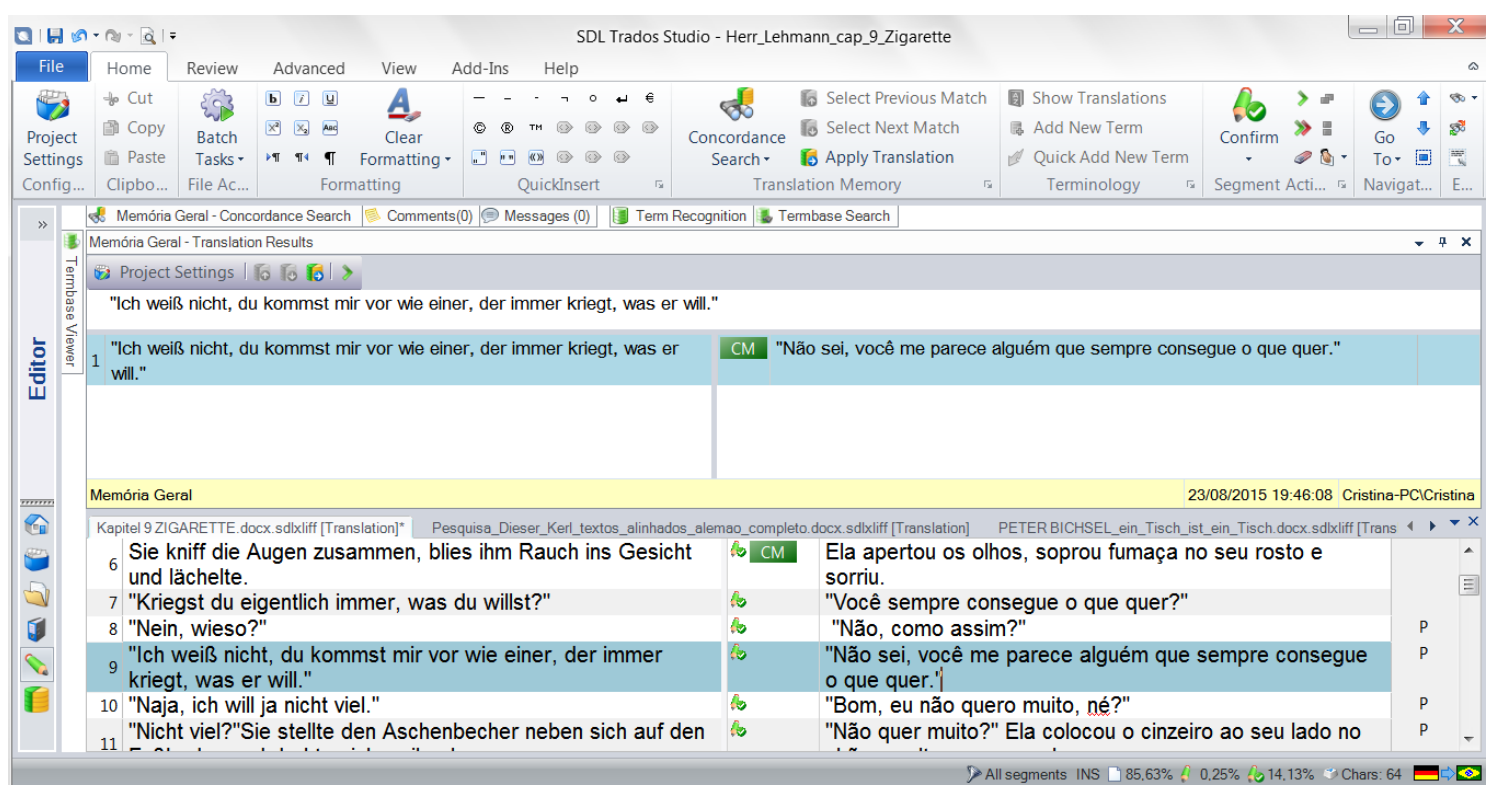

Figura 1: Interface do SDL-Trados 2014

O campo superior contém a barra de ferramentas. O campo central mostra a memória geral ou específica de um projeto, que são alimentadas pelo próprio tradutor ou por 
Guedes Evangelista, M. C. R. - Aprendizagem da língua alemã

vários tradutores, durante a tradução (FrOMM 2009: 10). Elas são constituídas por segmentos textuais e sua tradução, que também são colocados pelo programa no campo inferior destinado à tradução, sempre que o texto a ser traduzido (ou um novo texto) contiver um exemplo semelhante.

No campo inferior, pode-se observar, à esquerda, o texto na língua-fonte, separado em segmentos pelo próprio software, via de regra com base na pontuação. A coluna entre eles mostra os segmentos já aceitos e a porcentagem de correspondência entre o texto-fonte e a tradução, que pode variar entre Context Match (CM, quando os contextos em torno dos dois segmentos são correspondentes nas duas línguas), Exact Match (quando os contextos são diferentes) e Fuzzy Match (apontando uma porcentagem de semelhança entre os dois segmentos) (SDL-Trados 2017). À direita encontra-se o espaço destinado à tradução de cada segmento, que já está preenchido no projeto de tradução exposto na figura.

Portanto, uma memória de tradução pode ser utilizada em novas traduções, compartilhada com outros tradutores e integrada a outras ferramentas. Os programas gerenciadores de memórias de tradução permitem ainda a criação de glossários e a inserção de dicionários no mesmo ambiente, facilitando seu acesso durante a tradução.

\section{Objetivos}

O objetivo geral da pesquisa é testar formas de utilizar atividades escritas de tradução em fases iniciais da aprendizagem de alemão ( $1^{\circ}$ ano de estudo), partindo de textos simples em língua alemã, que incluem temáticas trabalhadas em sala de aula.

A partir dos objetivos específicos, pretende-se verificar:

a) Como os critérios selecionados com base em Aubert (1998), ScotT (1998) e Chesterman (1997) podem contribuir para a análise dos textos traduzidos pelos aprendizes para verificar: a aproximação com a língua-alvo (normalização), a manutenção de características da língua-fonte e os desvios por não compreensão da língua-fonte?

b) Como os aprendizes em fases iniciais da aprendizagem analisam as traduções, empregando os conhecimentos que possuem sobre a língua alemã?

c) Como um software gerenciador de memória de tradução pode auxiliar nesse tipo de atividade de tradução? 


\section{Metodologia}

\subsection{Aspectos gerais da pesquisa}

Esta pesquisa tem caráter exploratório (GIL 2002:41), porque busca “proporcionar maior familiaridade com o problema, com vistas a torná-lo mais explícito ou a construir hipóteses", por sua proposta de incluir atividades de tradução no ensino e na aprendizagem de LEs, em parte com auxílio de programas de memória de tradução, assim como de verificarde que maneira aprendizes de língua alemã realizam essas traduções e as avaliam em comparação com o texto-fonte.

Esse caráter exploratório também se aplica à tentativa de empregar a tradução como ferramenta metodológica desde os níveis iniciais da aprendizagem, um procedimento didático que geralmente é adotado em níveis posteriores da aprendizagem (Mendo Murillo 2009). Para enfocar esses níveis, a pesquisa foi realizada com estudantes do $1^{\circ}$ ano de curso de Letras de uma universidade pública, na disciplina

\section{Língua Alemã I.}

Esses estudantes elaboraram, com base no seguinte roteiro em língua alemã, uma apresentação pessoal que incluísse conteúdos estudados em aula a partir do material didático adotado:

\section{Quadro 7}

Roteiro para produção textual

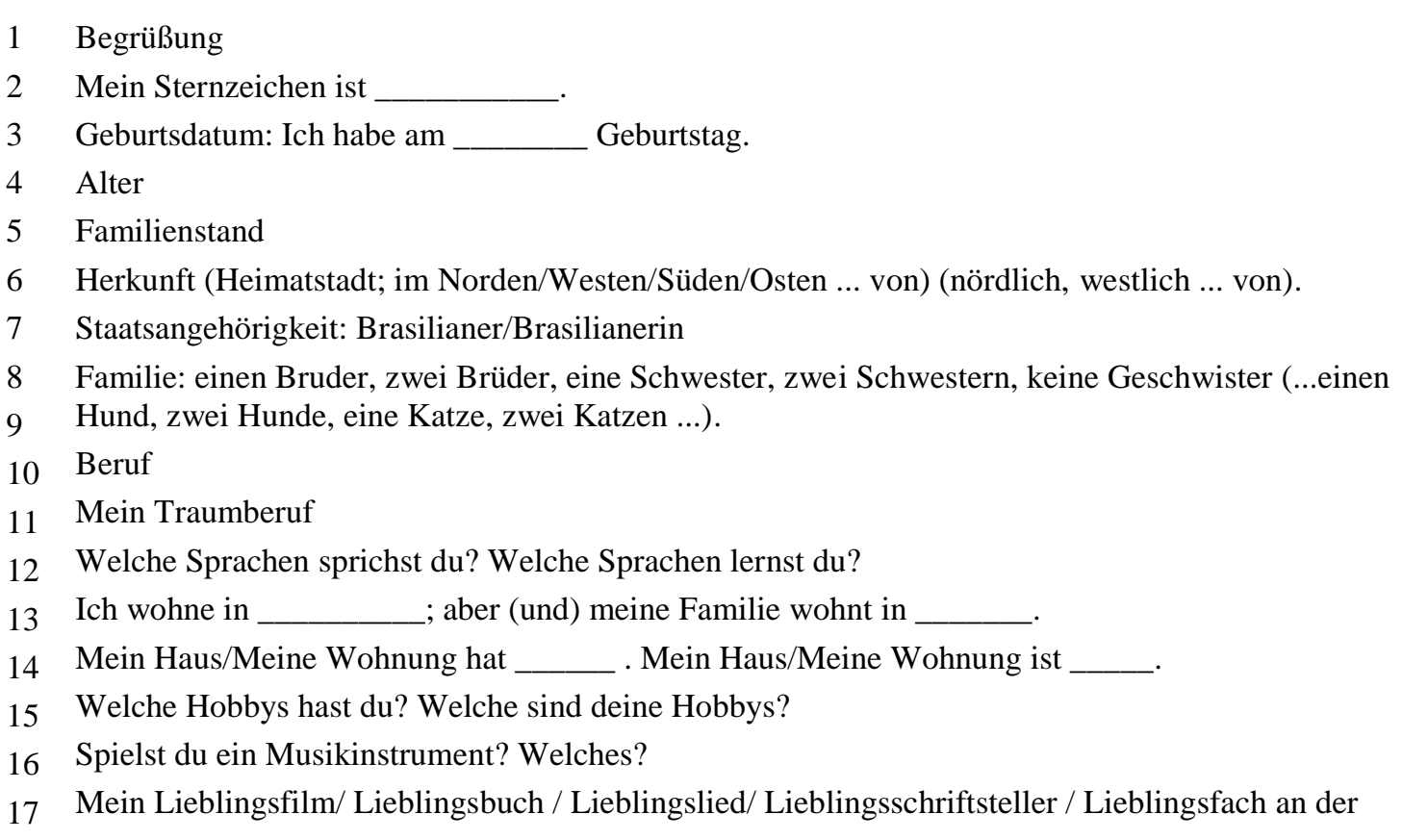


Guedes Evangelista, M. C. R. - Aprendizagem da língua alemã

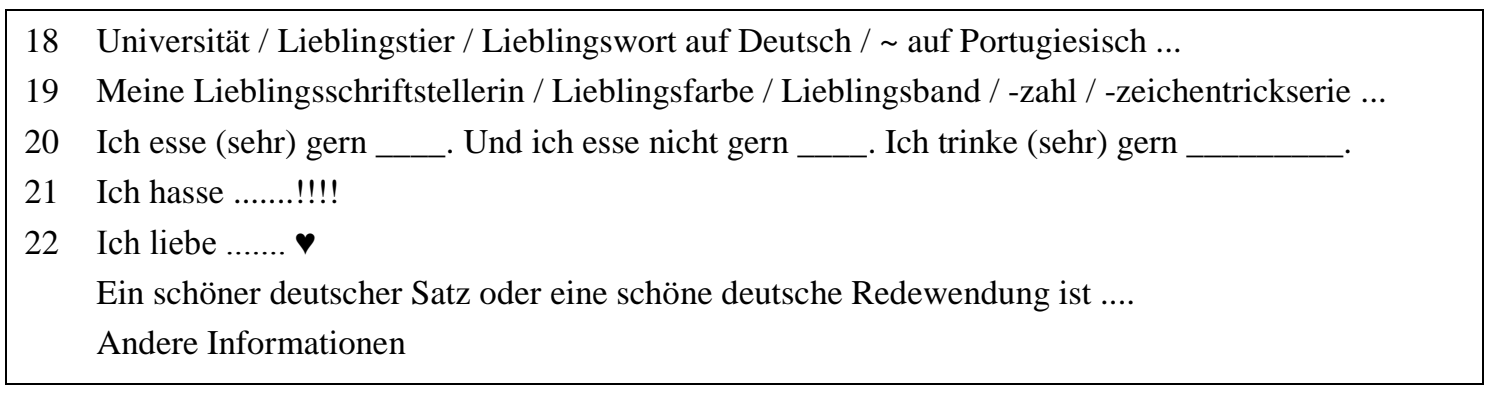

Os temas pouco conhecidos e/ou que apresentavam dificuldade foram explicados em sala de aula e em trocas de e-mails entre a docente-pesquisadora e cada aprendiz, realizadas até obtenção de textos adequados na língua alemã. Nessas trocas de e-mails, por meio de comentários acrescentados em notas à margem dos textos, os aprendizes foram estimulados a identificar e corrigir os problemas encontrados em seus textos.

$\mathrm{Na}$ etapa seguinte, os textos finais em língua alemã, corrigidos pela docente numa última leitura, foram distribuídos aleatoriamente entre os estudantes dos cursos diurno e noturno para serem traduzidos para o português.

As traduções foram primeiramente comparadas com os originais pela docentepesquisadora, buscando verificar como os aprendizes haviam entendido os textos em alemão e como eles os reconstruíam em português. Num período posterior, as traduções foram analisadas por quatro alunos de nova turma de $1^{\circ}$ ano, que não havia produzido texto semelhante, e por dois alunos do $2^{\circ}$ ano, da turma que produziu os textos.

Para essa análise, o grupo conheceu o software de memória de tradução SDLTrados. Os textos foram alinhados e comparados, discutindo-se inicialmente, em grupo, alguns trechos selecionados aleatoriamente, para verificar as soluções empregadas nas traduções. Na sequência, cada participante recebeu cerca de cinco (5) textos traduzidos para analisar e comentar individualmente. Somente um deles continuou as análises com auxílio do software.

\subsection{Identificação dos estudantes que avaliaram as redações}

Os estudantes que participaram da análise dos textos, chamados Avaliadores (Aval-1, Aval-2, Aval-3, Aval-4, Aval-5, Aval-6), têm as seguintes características: 
Guedes Evangelista, M. C. R. - Aprendizagem da língua alemã

a)Aval-1, Aval-6: contato com a língua alemã iniciado há 7 meses na disciplina Língua Alemã I; nível A1.1 a A1.2;

b) Aval-2: contato com a língua alemã por estudo autônomo antes de ingressar na faculdade, além da disciplina Língua Alemã I há 7 meses. Ao iniciar a graduação, apresentava nível próximo ao A2, sabendo interagir em língua alemã sem dificuldades; o único participante que utilizou o SDL-Trados durante toda a análise; nível A2.2;

c) Aval-3, Aval-4: frequentavam Língua Alemã II, tendo apresentado, no final do $1^{\circ}$ ano, nível A1.1;

d) Aval-5: contato com a língua alemã por estudo autônomo antes de ingressar na faculdade, além da disciplina Língua Alemã I há 7 meses; nível A1.2.

\section{$5.3 \bigcirc$ corpus analisado}

O corpus de análise contém 28 textos, com um total de 6.813 palavras em alemão e 7.146 palavras em português. O número de textos e de palavras analisado por cada avaliador, somando-se português e alemão, foi:Aval-1 (5/2416 pal.), Aval-2 (5/3039 pal., c/ SDL-Trados), Aval-3 (5/2148 pal.), Aval-4 (6/3078 pal.), Aval-5 (4/1630 pal.), Aval-6 (3/1648 pal.).

Os exemplos que seguem trazem o excerto do texto-fonte em alemão, identificado pelo número do texto (1 a 28), seguido da identificação da pessoa que apontou o exemplo, a docente ou um dos Avaliadores, informando-se o nível aproximado de conhecimento da língua alemã destes últimos. As traduções apresentadas juntamente com esses exemplos foram elaboradas pelos aprendizes.

\section{Análise e discussão das características das traduções}

\subsection{Normalização}

Neste trabalho, são estudadas as seguintes formas de normalização, de acordo com sua ocorrência nos textos analisados: pontuação, comprimento das sentenças, omissão, acréscimo, emprego de palavras mais usuais na língua-alvo, mudança coesiva e mudança na estrutura da oração. Na ocorrência de mais de uma característica no mesmo exemplo, elas são comentadas no mesmo tópico.

\footnotetext{
${ }^{6}$ Os níveis de proficiência na LE aproximados foram estabelecidos com base no rendimento dos estudantes em sala de aula e de acordo com a classificação do material didático utilizado em cada turma.
} 


\section{Pontuação/ Omissão}

As mudanças de pontuação (principalmente ponto, vírgula e ponto e vírgula) podem interferir no comprimento de orações, sentenças e textos. Elastambém podem referir-se ao uso de outros sinais, como aspas, reticências, parênteses, travessão etc.

(1) Ich wohne in Araraquara und bin Studentin von Beruf, studiere Portugiesisch und Deutsch und Latein.(T3, Aval-1, A1.1-A1.2)

Eu moro em Araraquara e sou estudante; estudo Português, Alemão e Latim.

A tradução traz mudança na pontuação, pois recebeu um ponto e vírgula ausente no texto-fonte. O Avaliador apontou que essa mudança na pontuação não seria necessária.

Esse exemplo também mostra a omissão do substantivo Beruf[profissão], que será comentada mais adiante.

Pontuação com mudança no comprimento da oração / Problema na tradução

(2) Leider ist mein Wohnzimmer auch sehr klein und ich will eine Bibliothek.(T3, Aval-1, A1.1-A1.2)

Assim como minha Sala de Estar é muito pequena. Eu gostaria de ter uma biblioteca.

O tradutor optou por uma mudança na pontuação, comentada pelo Avaliador, substituindo a conjunção und [e] pelo ponto final, provavelmente por observar que há um novo tema na segunda oração.

O exemplo traz ainda um erro na tradução da palavra leider [infelizmente], traduzida por "assim", apontado pelo Avaliador. Também chama a atenção as iniciais maiúsculas na expressão "Sala de Estar", utilizada desnecessariamente talvez por comparação com as regras ortográficas da língua alemã.

\section{Omissão / Tradução literal / Modulação}

A omissão pode ter objetivos variados, como, por exemplo, "manipular dados e evitar redundâncias, omitir termos explicativos contidos no TO [texto original] que possam parecer desnecessários" (CAMARGo 2010: 225). Segundo a definição de AUBERT (1997), na omissão a informação correspondente ao trecho omitido não pode ser 
Guedes Evangelista, M. C. R. - Aprendizagem da língua alemã

encontrada no texto-alvo, mas este não parece ser o caso nos exemplos encontrados no corpus analisado.

(3) Ich bin Studentin von Beruf und mein Traumberuf ist Lehrerin.(T2, docente)

Eu sou estudante e meu emprego dos sonhos é ser professora.

(4) Ich bin Studentin von Beruf.(T16, Aval-4, A1.1-A1.2)

Eu sou estudante de profissão.

Uma forma usual de informar a profissão em alemão é dizer IchbinStudentin von Beruf [Eu sou estudante de profissão]. Mas também é usual afirmar somente IchbinStudentin [Eu sou estudante]. Na tradução de (3), foi omitida a expressão“de profissão", possivelmente no entendimento de que ela não é necessária no português.

No entanto o corpus também apresenta a tradução literal, como no exemplo (4), na qual é mantida a expressão von Beruf, embora não seja usual em português.

Além dessa questão relativa à profissão, observa-se que o substantivo Traumberuf [profissão dos sonhos] foi traduzido em (3) por "emprego dos sonhos". Na descrição de AUBERT (1998: 108), uma das modalidades de tradução é a modulação, que se refere a um deslocamento semântico na tradução, que não compromete o "efeito geral de sentido". A preferência pela palavra "emprego" talvez possa ser um tipo de modulação, sendo necessário pesquisar os motivos que levam a esse uso, verificando se o tradutor considera que ele seja mais comum na língua-alvo ou se teria outras justificativas para essa escolha.

(5) Mein Haus ist groß und hell, es hat zwei Badezimmer, einen Garten, eine Garage, drei Schlafzimmer, [...].(T5, docente)

Minha casa é grande e clara, tem dois banheiros, um jardim, uma garagem, três quartos, $[\ldots]$.

Nesta tradução, é omitido o pronome de $3^{\mathrm{a}}$ pessoa do singular, es [ela/ele], referente ao substantivo neutro das Haus [a casa], utilizado na oração em língua alemã porque esta é uma língua de sujeito obrigatório, ao contrário do português, que aceita o sujeito nulo. Para AUBERT (1998), a omissão ocorre quando palavra ou segmento estão ausentes na tradução e não é possível recuperar seu significado. Este não seria o caso no exemplo (5). Mas SCOTT (1998 apud LiMA 2004) aponta que um dos objetivos da omissão é evitar redundâncias, explicação que seria adequada a este exemplo. 
Acréscimo/Omissão / Problema na compreensão da língua-fonte

Segundo NEWMARK (1988), o acréscimo é uma informação adicional que o tradutor acrescenta à tradução, por questões culturais, técnicas ou linguísticas.

(6) Mein Zimmer in einer WG ist sehr klein. (T24, docente)

Meu quarto de estudar é bem claro.

Neste exemplo, Zimmer[quarto], foi traduzido seguido do acréscimo de uma preposição e de um verbo, "quarto de estudar". Aparentemente o tradutor confundiu WG [Wohngemeinschaft - casa em forma de "república"] com Studentenwohnneim [moradia estudantil] e associou o quarto numa moradia com o estudo. Ao acrescentar "de estudar", ele omitiu a informação in einer $W G$ [numa república], como se esta última pudesse ser reconstituída pela primeira.

Além disso, o adjetivo klein [pequeno] foi erroneamente traduzida por "claro".

Emprego de palavras mais usuais na língua-alvo

Este é um indicador de normalização com diferentes ocorrências nos textos analisados. Uma delas é o verbo leben [viver], utilizado para indicar que a pessoa mora na cidade, na moradia estudantil ou com seus colegas. As traduções realizadas apresentam duas possibilidades, optando-se pelo verbo "viver", mais próximo do verbo alemão, ou pelo verbo "morar", que em alemão seria wohnen [morar]:

(7) Ich lebe im Studentenwohnheim der UNESP Araraquara. (T6, Aval-2, A2.2)

Eu vivo na moradia estudantil da UNESP Araraquara.

Ich lebe mit acht Personen. (T2, Aval-1, A1.1-A1.2)

Eu moro com oito pessoas.

O Avaliador-1 apontou que a opção pelo verbo "morar" seria mais adequada, por ser mais frequente na língua portuguesa.

Na língua alemã, a informação sobre a data de aniversário utiliza o verbo haben [ter]. A tradução literal desse verbo gera uma oração não utilizada em português:

Eu tenho em 19 Setembro aniversário. 
Guedes Evangelista, M. C. R. - Aprendizagem da língua alemã

O Avaliador comentou a inadequação da tradução na língua portuguesa. O tradutor não se preocupou com a língua-alvo, pois não utilizou a preposição "de" entre dia e mês. Alternativas encontradas no corpus para a tradução dessa expressão foram:

(10) Ich habe am 6. Mai Geburtstag, ich bin achtzehn Jahre alt und ich bin ledig.(T1, Aval1, A1.1-A1.2)

Eu faço aniversário no dia 06 de maio, eu tenho 18 anos e sou solteira.

O Avaliador concordou com a adoção da expressão "fazer aniversário", mais usual na língua portuguesa.

(11) Ich habe am 29. April Geburtstag. (T22, Aval-5, A1.2)

Meu aniversário é dia 29 de abril.

O Avaliador considerou a tradução adequada, comentando que o possessivo "meu" garante que não haja perda de significado, mantendo a referência ao sujeito ich [eu], expresso no trecho excluído, ich habe [eu tenho].

Em outro exemplo semelhante, o Avaliador apontou que a expressão "meu aniversário" pode ser aceita em português, embora "eu faço aniversário" seja usada com maior frequência.

Além desse trecho, o Avaliador comentou que, acertadamente, o tradutor utilizou o numeral cardinal para a data, uma vez que a língua portuguesa não utiliza o numeral ordinal para esse fim, como faz a língua alemã.

\section{Mudança coesiva/ Omissão / Modulação}

A mudança coesiva, como descrita por CHESTERMAN (1997apud CACHO; BRANCO 2014: 61), está relacionada ao uso de conectores:

(12) Ich spreche Portugiesisch und Englisch und kann ein bisschen Spanisch, Französisch und Deutsch sprechen.(T5, Aval-1, A1.1-A1.2)

Falo português e inglês, além de um pouco de espanhol, francês e alemão.

As duas orações ligadas por und [e] na língua alemã apresentam, na tradução, a mudança coesiva pela substituição da conjunção "e" pelo conector "além de". Na opinião do Avaliador, essa mudança não provoca alterações relevantes no significado. 
Guedes Evangelista, M. C. R. - Aprendizagem da língua alemã

Além dessa mudança, observa-se a omissão do pronome pessoal de $1^{\mathrm{a}}$ pessoa, ich [eu] na primeira oração.

A troca da perífrase verbal kann sprechen [sei falar] pelo verbo "falar" no presente do indicativo poderia ser entendida como modulação (AUBERT 1998).

Mudança na estrutura da frase

Segundo Chesterman (1997 apud CACHO; BRANCO2014: 61), essa mudança ocorre no grupo nominal ou no grupo verbal:

(13) Ich spreche Portugiesisch und lerne Deutsch und Englisch.(T5, Aval-1, A1.1-A1.2)

Eu falo português e estou aprendendo alemão e inglês.

Observa-se que o tradutor não manteve o presente do verbo lernen [aprender] do texto em alemão, adotando a forma nominal de gerúndio "estou aprendendo", mais usual no português para expressar uma ação em continuidade. Na língua alemã, essa ideia pode ser expressa pelos advérbios gerade [agora, neste momento] ou jetzt [agora]; uma perífrase verbal com o verbo estar + gerúndio não é utilizada. O Avaliador comentou essa questão, mas não teceu considerações sobre as possíveis formas de expressar, em alemão, uma ação ou processo em andamento.

\subsection{Manutenção das características da língua-fonte pela tradução literal}

Como apresentado no Quadro 4, a definição de tradução literal em AUBERT (1998: 106107) especifica que, em relação ao texto-fonte, são mantidos o "número de palavras", a "ordem sintática" e as "categorias gramaticais" e que as "opções lexicais" adotadas podem ser consideradas "sinônimos interlinguísticos".

(14) Ich kommeaus Sumaré, São Paulo.(T11, Aval-3, A1.1)

Eu venhode Sumaré, São Paulo.

(15) Ich wohne in Araraquara, aber ich komme aus Sorocaba.(T. 22, Aval-5, A1.2)

Eu moro em Araraquara, mas eu sou de Sorocaba.

(16) Ich komme aus Brasilien, aus der Stadt Marília und wohne in Araraquara.(T2, docente) Eu vim do Brasil, da cidade de Marília e moro em Araraquara. 
Guedes Evangelista, M. C. R. - Aprendizagem da língua alemã

A tradução do verbo kommen [vir] foi realizada de diferentes formas nos textos analisados, utilizando-se, no português, "eu venho" ou "sou de". A opção com o verbo "ser" (15) recebeu aprovação de diferentes Avaliadores, pois parece mais frequente em portuguêsnesse contexto do que "vir".

No exemplo (16),o Avaliador comentou que houve modificação nas ideias do autor do texto, pela alteração do tempo verbal do verbo "vir", usado no presente no texto-fonte e no pretérito perfeito na tradução.

(17) Ich esse nicht gern die meisten Obstsorten.(T11, Aval-3, A1.1)

Eu não gosto de comer a maioria das qualidades de frutas.

O Avaliador comentou a tradução literal da palavra Obstsorten [qualidades ou tipos de frutas] pela expressão "qualidades de frutas", pouco comum na língua portuguesa.

Ich bin hier geboren. (T16, Aval-4, A1.1)

Eu sou nascida aqui.

O Avaliador apontou que a tradução ficaria mais adequada na língua portuguesa com a expressão "nasci aqui".

Ich arbeite nicht; ich bin Studentin.(T12, Aval-3, A1.1)

Eu não trabalho; eu sou estudante.

Neste exemplo, o Avaliador questionou a necessidade de repetir o pronome "eu" na segunda oração na tradução, uma vez que ele se encontra na oração anterior.

(20) Meine Heimatstadt ist Jales, diese Stadt liegt im Nordwesten von São Paulo.(T7, Aval2, A2.2)

Minha cidade natal é Jales, esta cidade está no noroeste de SP.

Para o Avaliador, as traduções literais de meine Heimatstadt por "minha cidade natal" e diese Stadt por "esta cidade" poderiam ter sido substituídas por outras expressões ou mesmo por uma oração subordinada "Eu nasci em Jales, que fíca no noroeste de SP".

(21) Ich kann Englisch, Portugiesisch und nur ein bisschen Französisch sprechen.(T8, Aval$2, \mathrm{~A} 2.2)$ 
Guedes Evangelista, M. C. R. - Aprendizagem da língua alemã

Eu consigo falar inglês, português e um pouco de francês.

O Avaliador comentou que a tradução literal poderia ser substituída pela oração mais adequada na língua portuguesa: "Eu falo inglês, português e um pouco de francês."

Para manter a estrutura perifrástica kann sprechen [sei falar] presente no texto em alemão, a tradução poderia ser: "Sei falar inglês, português e um pouco de francês".

Ich bin zwanzig Jahre alt.(T18, Aval-1, docente)

Eu tenho vinte anos de idade.

Na língua alemã, a idade é expressa de modo semelhante ao que é feito na língua inglesa em I am 20 years old. Em português, o mais usual seria dizer "Tenho 19 anos", mas o tradutor empregou a expressão "de idade", buscando manter o significado do adjetivo alt [velho]. Houve comentários de Avaliadores a esse respeito em outras ocorrências: Aval-1 afirma que a tradução que mantém "de idade" não é adequada ao português (textos 3,4). Aval-5 concorda com o tradutor, pois evitaria utilizar "de idade", mas aponta que esse trecho poderia ser incluído na tradução "considerando que o texto original contém a expressão completa" (texto 22). Outros três Avaliadores tiveram ocorrências semelhantes mas não as comentaram. Observe-se, ainda, que a tentativa de manter o significado integral do texto-fonte leva a uma transposição, quando o adjetivo é traduzido por um substantivo.

\subsection{Problemas na tradução por falta de compreensão da língua-fonte}

Esta categoria corresponde à modalidade de tradução denominada "Erro" por AUBERT (1998). Neste trabalho, mais do que uma avaliação quanto à correção ou incorreção dos

textos traduzidos, interessa observar o tipo de fenômeno que determina a falta de compreensão.

23) Ich komme aus dem Osten von São Paulo, ich bin Brasilianerin.(T5, docente)

Eu venho de mais a oeste (Osten-leste) de São Paulo, eu sou de Brasília.

O aprendiz-tradutor avaliou que havia um erro no texto-fonte, porque, para ele, ausdemOstenvon São Paulo [do leste de São Paulo] seria referência a um ponto "no meio do mar". Mas essa expressão pode indicar um local situado no lado leste do estado 
Guedes Evangelista, M. C. R. - Aprendizagem da língua alemã

de São Paulo. Para designar um local fora do estado, seria utilizado o advérbio östlich von [a leste de]. A diferença entre as duas formas de localizar pontos geográficos em alemão, $X$ liegt im Osten von Z [X está localizada no leste de Z], quando X está dentro de Z, como na relação entre cidade e estado ou, ao contrário, $Y$ liegt östlich von $Z$ [Y liegt a leste de Z], quando os dois pontos são independentes entre si, como duas cidades, geralmente traz dificuldades para aprendizes.

O tradutor também não reconheceu o substantivo que, na língua alemã, designa o país de origem, Brasilianerin [brasileira], traduzindo-o por “de Brasília”, que contribuiu para que não compreendesse esse trecho.

\section{Meine Heimatstadt ist im Osten von São Paulo.(T4, docente)}

Minha cidade natal é São Paulo, na zona leste.

O trecho apresenta outra falha na interpretação dessa expressão. A cidade natal está localizada im Osten von São Paulo [no leste de São Paulo], referindo-se ao estado, mas o tradutor remete à cidade de São Paulo e à sua "zona leste". Ele parece não ter partido da leitura do texto como um todo, fixando-se somente na tradução de orações isoladas, pois não percebeu que, na oração anterior, o autor diz que nasceu na cidade de Araraquara.

Ich studiere Sprachen von Montag bis Freitag an der UNESP, aber arbeite nicht.(T5, docente)

Eu estudo línguas de segunda a sexta-feira na UNESP, mas trabalho à noite.

A palavra nicht [não] foi confundida com Nacht [noite], causando um erro na tradução. A semelhança entre as duas palavras poderia causar essa troca, mas o tradutor poderia ter recorrido à ortografia, pois os substantivos na língua alemã sempre têm a letra inicial maiúscula, de forma que nicht não poderia ser um substantivo.

(26) Die Küche hat einen Herd, einen Kühlschrank und einen Tisch.(T18, Aval-4, A1.1)

A cozinha tem um fogão, um armário de cozinha e uma mesa.

O Avaliador apontou que o substantivo composto Kühlschrank [geladeira] foi traduzido erroneamente por "armário de cozinha" e comentou que o tradutor deve ter se orientado somente pelo último componente desse substantivo, que define gênero e número dos substantivos compostos alemães, que é Schrank [armário]. 
Eu gosto de beber muita água.

O uso de gern constitui uma dificuldade para aprendizes de alemão, porque esse advérbio é empregado após o verbo da oração, para indicar o gosto por algo. A tradução literal seria "eu bebo com muito gosto água". Traduções adequadas à língua portuguesa seriam "gosto muito de beber/tomar água" ou "gosto muito de água". Nesse caso, o tradutor reconheceu o gern como expressão da ideia "gostar de", mas mudou escopo do intensificador sehr, o qual, na língua-fonte, incide sobre o advérbio e, na tradução, modifica o sentido original ao incidir sobre o substantivo "água'.

(28) Ich habe keine Brüder oder Schwestern, aber ich habe eine Kusine, die mir sehr nah ist.(T4, docente)

Eu não tenho irmãos ou irmãs, mas eu tenho um primo que é muito próximo de mim.

O aprendiz-tradutor não identificou a forma feminina Kusine [prima]. O pronome relativo feminino que segue esse substantivo provavelmente ainda não auxiliaria os aprendizes nesse nível de aprendizagem, porque esse é um tópico abordado em níveis um pouco mais adiantados.

(29) Ich mag die Wörter ,, schönen “ auf Deutsch und,,maravilha “ auf Portugiesisch [...].(T1, Aval-1, A1.1-A1.2)

Eu gosto da palavra „schönen” (bonito) em alemão e “maravilha” em português [...].

O tradutor não identificou o plural die Wörter [as palavras], mesmo havendo citação de duas palavras logo após, o que exige esse plural.

Ich trinke sehr gern Wasser und Traubensaft.(T23, Aval-5, A1.2)

Eu gosto muito de beber água e comer sonho.

Tradução equivocada da palavra Traubensaft [suco de uvas] por "sonho", possivelmente pela associação com a palavra Traum [sonho] ou Träume [sonhos]. Ele também não reconheceu a palavra-base do substantivo -saft, que significa "suco" e faz parte do vocabulário utilizado nesse nível. O Avaliador comentou que "sonho" é o correspondente brasileiro ao doce Berliner e por isso o tradutor deve ter acrescentado o verbo “comer" para completar o sentido da oração. 
Guedes Evangelista, M. C. R. - Aprendizagem da língua alemã

(31) Ich habe keine Brüder oder Schwestern, aber ich habe einen Hund.(T24, Aval-5, A1.2) Tenho um irmão, uma irmã e um cachorro.

O Avaliador comentou que o tradutor não considerou a negação keine e, por isso, traduziu a primeira oração como uma afirmativa.

(32) Im Studentenwohnheim der UNESP Araraquara teile ich mein Schlafzimmer mit einem Kollegen.(T6, Aval-2, A2.2)

Na moradia estudantil da UNESP Araraquara divido meu quarto com umacolega.

O exemplo mostra que o substantivo Kollege [colega] não foi reconhecido como masculino. O gênero desse substantivo poderia ter sido visualizado pelo artigo indefinido no caso dativo, einem, que pode anteceder um substantivo neutro ou masculino e se diferencia de einer, que antecederia um substantivo feminino.

Ich bin ledig, aber ich habe einen Freund.(T7, Aval-2, A2.2)

Sou solteira, mas eu tenho um amigo.

O tradutor não analisou o contexto para compreender que a palavra Freund refere-se ao "namorado" e não a um "amigo". Essa questão é alvo frequente de comentários dos aprendizes, que não entendem como é possível diferenciar essas duas acepções da palavra Freund.

Ich liebe auch mein Haus.(T12, Aval-3, A1.1)

Eu moro na minha casa.

O verbo lieben [amar] foi confundido com o verbo leben [viver], como registrou o Avaliador. A preposição "na" foi acrescentada na tradução. O advérbio "também" foi omitido na tradução.

Para concluir este tópico referente à análise de traduções como forma de visualizar e compreender questões relacionadas à aprendizagem de línguas, são comentados trechos contendo a análise de um só Avaliador para questões diferentes.

(35) Die Schlafzimmer des Hauses verfügen über zwei Einzelbetten, einen Einbauschrank und einen an der Wand eingebauten Schreibtisch. (T6, Aval-2, A2.2)

$\mathrm{O}$ quarto da casa tem duas camas, um armário, e uma escrivaninha.

[Os quartos da casa têm duas camas de solteiro, um armário embutido e uma escrivaninha fixada na parede.] 
O Avaliador, que possuía nível A2.2 de conhecimento de alemão, realizou uma análise abrangente das características do trecho, propondo a nova tradução, colocada entre colchetes. Ele comentou que o tradutor:(a) não percebeu o artigo e o verbo no plural; (b) simplificou a expressão "armário embutido", utilizando somente armário; (c) simplificou ao traduzir Einzelbetten [camas de solteiro]por "camas" e (d) omitiu a explicação sobre a escrivaninha fixada na parede.

(36) Sie können Menschen aus anderen Städten kennen lernen und mit der Vielfalt leben. (T6, Aval-2, A2.2)

Você pode conhecer pessoas (?), aprender e conviver com a diversidade e conhecer outras cidades (?).

Nesse exemplo, o tradutor deixou pontos de interrogação para assinalar dúvidas. A insegurança na tradução pode ser atribuída ao não reconhecimento do verbo kennenlernen como um só verbo, que pode ser traduzido por "conhecer", o que levou ao emprego errôneo de dois verbos diferentes na tradução, "conhecer" e "aprender", apontado pelo Avaliador. Este também comentou que o tradutor não reconheceu ausanderen Städten [de outras cidades] como expressão que modifica o substantivo Menschen [pessoas], traduzindo-a como "conhecer outras cidades".

\section{Considerações finais}

Este trabalho teve como objetivo geral, partindo de textos adequados para o nível de conhecimento de LE dos aprendizes, verificara utilização da tradução e da análise de traduções, em fases iniciais da aprendizagem, como recursos metodológicos que contribuam para a aprendizagem.

Fundamentando-se em AUBERT (1998), ScOtT (1998 apud LiMA 2004) e CHESTERMAN (1997 apud CACHO; BRANCO 2014: 61), foram formuladas três categorias paraobservar as características dos textos traduzidos: sua aproximação com a línguaalvo (normalização), a manutenção de características da língua-fonte e problemas na tradução.

Por meio dessas características dos textos traduzidos, o professor de LE pode avaliar o modo como os aprendizes compreendem a língua-alvo. Os problemas verificados podem estar relacionados ao conhecimento ainda limitado das características 
Guedes Evangelista, M. C. R. - Aprendizagem da língua alemã

da LE na fase inicial da aprendizagem. Quando as dificuldades envolvem temas já tratados em sala de aula, esse tipo de ocorrência pode ter um caráter diagnóstico para o professor e para o aprendiz, que poderão buscar (novas) formas de abordar os fenômenos em questão, revisando-os e promovendo seu aprendizado.

O bom desempenho na análise de orações mais complexas obtido por um estudante com nível aproximado A2.2 de conhecimento da língua alemã (exemplos 35 e 36), assim como a falta de percepção de alguns problemas na tradução por outros aprendizes, levam a refletir sobre como explorar e comentar tais tarefas de tradução em sala de aula. As dificuldades de alguns aprendizes possivelmente poderão ser superadas pela discussão das traduções em grupos e em projetos colaborativos de tradução nos quais os pares mais desenvolvidos servirão de apoio aos demais, como proposto na visão vygotskyanasobre a aprendizagem, retomada por GABALLO (2008).

Como recurso computacional de apoio à tradução, além de dicionários online, buscou-se orientar os aprendizes na utilização de uma ferramenta de criação e gerenciamento de memórias de tradução. Com auxílio dessa ferramenta, criou-se um bitexto, que facilita a visualização simultânea do texto-fonte e da tradução. A criação da memória de tradução e de glossários e a possibilidade de inserir dicionários no programa são outras vantagens que justificam seu uso por aprendizes, embora ainda sejam necessárias pesquisas sobre formas de utilização dessas funcionalidades no ensino e na aprendizagem de LE.

É necessário observar que, para realizar o alinhamento de textos e registrar os comentários sobre eles, há outros programas mais simples do que os softwares de gerenciamento de memória de tradução. Mas, ao utilizar tais softwares, o aprendiz de LE tem a oportunidade de visualizar continuamente, enquanto traduz, os segmentos dos dois textos e trechos mais amplos do texto, assim como as soluções apontadas pela memória de tradução. Com isso, ele tem a oportunidade de avaliar se as traduções armazenadas na memória são adequadas ou não em novos contextos. A integração de todas as funcionalidades desses softwares, entre as quais estão memórias de tradução, glossários e ferramentas de gerenciamento de terminologia, pode representar um ganho para os aprendizes, inclusive por colocá-los em contato com questões que fazem parte da vida profissional dos tradutores.

A pesquisa mostra que atividades de tradução em fases iniciais da aprendizagem de línguas trazem diversos aspectos positivos: 
- A tradução pode levar à repetição e fixação de vocabulário e de estruturas estudados;

-As tarefas de tradução motivam o aprendiz, porque há um resultado concreto para seu trabalho: o texto traduzido.

- A tarefa de traduzir textos adequados a seu nível motiva os aprendizes, porque os textos são compreensíveis para eles. Porém, mostra-se útil a troca de textos entre os aprendizes, pressupondo-se que, deste modo, eles comparem esses textos com sua própria produção textual e, além disso, possam ter contato com palavras ou estruturas desconhecidas, escolhidas pelos colegas, cuja tradução exige reflexão e pesquisas mais aprofundadas;

- Os aprendizes são levados a perceber semelhanças e diferenças entre sua língua materna e a LE;

- A análise de traduções constitui uma nova abordagem, que leva os aprendizes a examinarem com atenção o texto na LE e pensar em alternativas para expressar as ideias nas duas línguas;

No que diz respeito aos resultados desta pesquisa para minha própria prática como docente, a busca por atividades de tradução para aprendizes em níveis iniciais de aprendizagem vem possibilitando a ampliação de meu repertório metodológico e apresenta novas questões a serem pesquisadas.

Observa-se, ainda, que o trabalho com a tradução nesse nível, que tem como intuito principal a aprendizagem de LE, permite abordar questões referentes ao ensino de tradução e ao exercício da profissão de tradutor, por exemplo na avaliação dos textos traduzidos quanto à sua adequação à língua portuguesa.

Pelo envolvimento dos aprendizes com as tarefas propostas, ficou mais uma vez evidenciado o interesse dos alunos do curso de Letras pela tradução. Nesse sentido, uma aproximação ainda maior entre os estudos da tradução e os estudos relativos ao ensino e a aprendizagem de línguas poderá contribuir de forma positiva para as duas áreas e para atender essa demanda relacionada aos estudantes.

\section{Referências bibliográficas}

ADARVE MARTINEZ, S. L. Diseño de materiales para mejorar la expresión escrita mediante actividades de traducción pedagógica. Dissertação (Mestrado em Linguística Aplicada). Universidade de Jaén, Jaén, 2012-2013. Disponível em: <2014_BV_15_08Adarve.pdf>. Acesso em: 15 maio 2017.

ALEGRE, T. A tradução pedagógica no actual ensino de línguas: o caso do alemão. In: Actas do $5^{\circ}$ Encontro Nacional sobre o Ensino das Línguas Vivas no Ensino Superior, 2002, 1128. Disponível em: <http://ler.letras.up.pt/uploads/ficheiros/6257.pdf>. Acesso em: 15 maio 2017. 
ALVES, M. P. Traduzir para adquirir vocabulário em língua estrangeira. Dissertação (Mestrado em Linguística Aplicada). Universidade de Brasília, Brasília, 2007. Disponível em: <http://repositorio.unb.br/handle/10482/3035>. Acesso em: 15maio2017.

ARRANZ, J. Forgiven, not forgotten: Communicative translation activities in second language teaching. Revista alicantina de estúdios ingleses, Alicante, n. 17, p. 239-259, 2004. Disponível em: <https://rua.ua.es/dspace/bitstream/10045/55292/1/RAEI_17_21.pdf>. Acesso em: 15 maio 2017.

ATKINSON, D. The mother tongue in the classroom: a neglected resource? ELT J, v. 41, n. 4, p. 241-247, 1987.

AUBERT, F.H. Modalidades de tradução: teorias e resultados. TradTerm, São Paulo, v. 5. n. 1, p. 99-128, 1998.Disponível em: <http://www.revistas.usp.br/tradterm/article/view/49775>. Acesso em: 15 maio 2017.

AZENHA JR., J. O lugar da tradução na formação em Letras: algumas reflexões. Cadernos de Tradução, Florianópolis, UFSC, v. 1, n. 17, 2006. Disponível em: <https://periodicos.ufsc.br/index.php/traducao/article/view/6860>. Acesso em: 15 maio 2017.

BoHUNOVSKI, R. A. tradução no ensino de línguas: vocabulário, gramática, pragmática ou consciência cultural? Trabalhos em linguística aplicada, Campinas, v. 50, n.1, 2011. Disponível em: <https://periodicos.sbu.unicamp.br/ojs/index.php/tla/article/view/8645348>. Acesso em: 15 maio 2017.

BRANCO, S. de O. Teorias da tradução e o ensino de língua estrangeira. Revista Horizontes de Linguística Aplicada, Brasília, v. 8, n. 2, p. 185-199, 2009. Disponível em: <http://periodicos.unb.br/index.php/horizontesla/article/view/2941>. Acesso em: 15 maio 2017.

BRANCO, S. de O. Os estudos da tradução no Brasil: Relatos de pesquisa. Traduzires, Brasília, v. 1 n. $\quad 1, \quad$ p. 49-60, 2012. Disponível em: <http://periodicos.unb.br/index.php/traduzires/article/view/6654>. Acesso em: 15 maio 2017.

BRIKS, F. J. P. Tradução: Ferramenta eficaz no ensino-aprendizagem de línguas estrangeiras para o aluno do ensino superior. Belas Infiéis, Brasília, v. 1, n. 1, p. 153-167, 2012. Disponível em: <http://periodicos.unb.br/index.php/belasinfieis/article/viewFile/7540/5818>. Acesso em: 15 maio 2017.

ButZKAMM, W. Die kompliziertere Lösung ist die richtige: Aufgeklärte Einsprachigkeit. Rückblick und Ausblick. Der fremdsprachliche Unterricht, v. 24, n. 104, p. 4-17, 1990. Disponível em: <http://www.fremdsprachendidaktik.rwth-aachen.de/Ww/dfu24104.pdf>. Acesso em: 15 maio 2017.

CACHO, M. B.; BRANCO, S. Análise das estratégias de tradução sintáticas em textos traduzidos por alunos de Letras. Cultura e tradução, João Pessoa, v. 3, n. 1, 2014. Disponível em: <http://periodicos.ufpb.br/index.php/ct/article/view/21525>. Acesso em: 15 maio 2017.

CAMARGO, D. C .de. Uma investigação de aspectos de normalização na autotradução $N a$ invincible memory. TradTerm, n. 16, p. 217-230, 2010. Disponível em: <http://www.revistas.usp.br/tradterm/article/view/46319>. Acesso em: 15 maio 2017.

CONSELHO DA EUROPA. Quadro europeu comum de referência para as línguas. Aprendizagem, ensino, avaliação. Porto: ASA, 2001a. Disponível em: <http://www.dge.mec.pt/quadroeuropeu-comum-de-referencia-para-linguas >. Acesso em: 10 maio 2017.

CONSElho DA Europa. Portfolio europeu de línguas. Ministério da Educação. Portugal, 2001. Disponível em: <https://www.dge.mec.pt/sites/default/files/ficheiros/portefolio_europeu_linguas_2_3ci clo.pdf>. Acesso em:15 maio 2017. 
Guedes Evangelista, M. C. R. - Aprendizagem da língua alemã

CORRÊA, E. F. DE S.A língua materna e a tradução no ensino-aprendizagem de língua nãomaterna: uma historiografia crítica. Tese (Doutorado em Estudos da Linguagem). Pontifícia Universidade Católica do Rio de Janeiro, 2014. Disponível em: <http://www.dbd.puc-rio.br/pergamum/tesesabertas/1112745_2014_completo.pdf >. Acesso em: 15 maio 2017.

DE ARRIBA GARCIA, C. Introducción a latraducción pedagógica. Lenguaje y Textos, n. 8. SEDLL: Universidade da Coruña, $1996 . \quad$ Disponívelem: <uc.udc.es/dspace/bitstream/handle/2183/7979/LYT_8_1996_art_17.pdf?sequence=1 >. Acesso em: 15 maio 2017.

EICHHEIM, Het al. Blaue Blume. Tradução de Paulo Oliveira e Susana Kampff Lages. 2. ed. Campinas: Editora da UNICAMP, 2011.

FromM, G. Ferramentas de auxílio e terminologia: algumas considerações para aprendizes de tradução e seus cursos. Revista Linguística, v. 5, n. 2, 2009. Disponível em: <https://revistas.ufrj.br/index.php/rl/article/view/4428>.Acesso em: 15 abr. 2017.

FunK, H.; KUHN, C.; DEMME, S. Studiod A1. Kurs- und Übungsbuch. Berlin: Cornelsen, 2005.

GABALLO, V. Learning translation strategies in a CSCL framework. Knowledge Construction in E-learning Context.Achen (D): CEUR Workshop Proceedings, v. 398, p. 1-4, 2008. Disponível em: 〈http://ceur-ws.org/Vol-398/S6_Gaballo.pdf〉. Acesso em: 15 maio 2017.

GIL, A. C. Como elaborar projetos de pesquisa. 4. ed. São Paulo: Atlas, 2002.

GONZÁLEZ DAVIES, M. Humanising translation activities: Tackling a secret practice. Humanising Language Teaching, ano4, n. 4. Disponível em: <http://www.hltmag.co.uk/jul02/mart2.htm>. Acesso em: 15 maio 2017.

HARRIS, B. Bi-text, a new concept in translation theory. Language Monthly, n. 54, p. 8-10, 1988. Disponível em: <http://mt-archive.info/LangMonthly-54-1988-Harris.pdf〉. Acesso em: 15 maio 2017.

KELLER, M. C.O uso da tradução no ensino de línguas estrangeiras. Seminário de Leitura e Produção Textual, v. 2, n. 2, 2012. Disponível em: <http://periodicos.unesc.net/index.php/selep/article/view/632/635>. Acesso em: 15 maio 2017.

LAIÑO, M. J.A tradução pedagógica como estratégia à produção escrita em LE a partir do gênero publicidade. Tese (Doutorado em Estudos da Tradução). Universidade Federal de Santa Catarina, Florianópolis, 2014. Disponível em: <https://repositorio.ufsc.br/handle/123456789/128637>. Acesso em: 15 maio 2017.

LIBERATTI, E.A tradução na sala de aula de LE: (des)construindo conceitos. Entrepalavras, Fortaleza, ano 2, v.2, n.1, p. 175-187, 2012. Disponível em: <http://www.entrepalavras.ufc.br/revista/index.php/Revista/article/view/50>. Acesso em: 15 maio 2017.

LiMA, T. C. de S.A tradução e os prazeres de descobrir o mundo de Clarice Lispector. Dissertação (Mestrado em Estudos Linguísticos). Instituto de Biociências, Letras e Ciências Exatas - IBILCE, São José do Rio Preto, 2004. Disponível em: $<$ https://repositorio.unesp.br/bitstream/handle/11449/93915/lima_tcs_me_sjrp.pdf;seque nce $=1>$. Acesso em: 15 maio 2017.

LUCINDO, E. S. Tradução e ensino de línguas estrangeiras. Scientia Traductionis, Florianópolis, v. $1, \quad$ n. $3, \quad$ nov. $2006 . \quad$ Disponível em: <periodicos.ufsc.br/index.php/scientia/article/view/12933>. Acesso em: 15 maio 2017.

MURILLO, S. M. El uso de la traducción em losprimeros niveles de E/LE. redELE Revista electrónica de didáctica / español lengua extranjera, n. 17. Disponível em: <http://www.mecd.gob.es/dctm/redele/Material-

RedEle/Revista/2009_17/2009_redELE_17_03Mendo.pdf?documentId=0901e72b80dd 6fd6>. Acesso em: 26 abr. 2017. 
Guedes Evangelista, M. C. R. - Aprendizagem da língua alemã

NeWMarK, P. A textbook of translation. London: Prentice Hall, 1988.

Nomura, M.; AzEnHA JR., J.O texto como unidade de trabalho no ensino de línguas e de tradução. Pandaemonium Germanicum, v. 14, n. 2, p. 218-242, 2009. Disponível em: <http://dx.doi.org/10.1590/S1982-88372009000100012>. Acesso em: 15 maio 2017.

Pym, A. Gutiérrez-Colón Plana, M. d. M.; MAlmkJaer, K. Translation and language learning: The role of translation in the teaching of languages in the European Union. A Study. Directorate-General for Translation, European Commission. 15 July 2013. Disponível em: <http://www.termcoord.eu/wpcontent/uploads/2013/08/European_Commission.pdf>. Acesso em 23 abr. 2017.

RAZUK, R. DE O. Interfaces entre a tradução e o PL2-E: As estratégias usadas pelos alunos estrangeiros na produção de textos em português. Revista Letra Magna, ano 1, n. 1, 2004. Disponível em: 〈http://www.letramagna.com/renataoliveirarazuk.pdf〉. Acesso em: 15 maio 2017.

RIDD, M. Bibliografia de referência sobre Tradução no Ensino e Aprendizagem de Línguas. Horizontes de Linguística Aplicada, v. 8, n. 2, p.255-296, 2009. Disponível em: <http://periodicos.unb.br/index.php/horizontesla/article/view/2946/0>. Acesso em: 23 abr. 2017.

RochA, N. F. Tradução literal e aprendizagem de línguas estrangeiras: uma estratégia para memorização. In-Traduções. Revista do Programa de Pós-graduação em Estudos da Tradução da UFSC, v. 3, n. 5, 2011. Disponível em: <http://incubadora.periodicos.ufsc.br/index.php/intraducoes/article/view/1809>. Acesso em: 18 out. 2015.

ROMANELLI, S. O uso da tradução no ensino-aprendizagem das línguas estrangeiras. Horizontes de Linguística Aplicada, Brasília, v. 8, n. 2, p. 200-219, 2009. Disponível em: <http://periodicos.unb.br/index.php/horizontesla/article/viewFile/2942/2546>. Acesso em: 15 maio 2017.

SDL-TRADOS. SDL TRADOS STUDIO 2017. Disponível em: $<$ http://docs.sdl.com/LiveContent/content/en-US/SDL\%20Trados\%20Studio\%20Helpv4>. Acesso em: 15 maio 2017.

TeCChio, I.; BittencourT, M. J. G.A tradução no ensino-aprendizagem de línguas estrangeiras. Revista Magistro, v. 2, n.1, 2011. Disponível em: <http://publicacoes.unigranrio.edu.br/index.php/magistro/article/view/1471/765>. Acesso em: 15 maio 2017.

Williams, J.; CHESTERMAN, A. Areas in translation research. The Map. A beginner's guide to doing research in Translation Studies. Manchester: St. Jerome, 2002. p. 6-7. 